Copyright (C) 2021 by Cherkas Global University

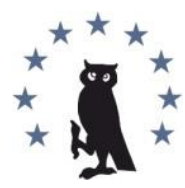

Published in theUSA

Propaganda in the World and Local Conflicts

Has been issued since 2014 .

E-ISSN 2500-3712

2021. 8(2): $87-92$

DOI: $10.13187 /$ pwlc.2021.2.87

https://pwlc.cherkasgu.press

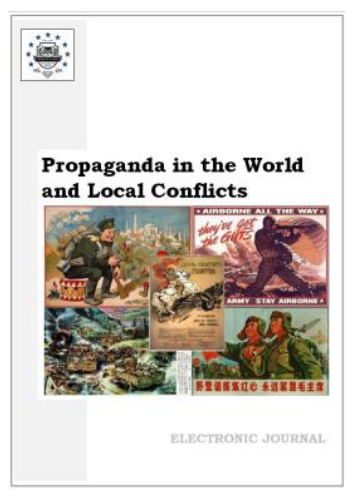

\title{
The Arsenal of Psychological Tools and Methods Employed by the Wehrmacht on the Eastern Front in the Area of Operation of the Red Army's $128^{\text {th }}$ Rifle Division (May-July 1944)
}

\author{
Sergey N. Nikitin a
}

a American Historical Association, Washington, USA

\section{Abstract}

This paper examines the arsenal of psychological tools and methods employed by the Wehrmacht on the Eastern Front in the period from May through July 1944 based on materials from the operational and intelligence reports of the headquarters of the Red Army's $128^{\text {th }}$ Rifle Division.

Principal use was made of materials from the Central Archive of the Ministry of Defense (Podolsk, Russian Federation). This was the first time the documents had been introduced into general circulation.

Methodologically, in reliance on the principles of objectivity and historicism, the author sifted through every archive material on the subject available. Importantly, use was also made of a systems approach, with all the relevant propaganda influence facts being arranged and systematized based on the chronological principle.

The author's conclusion is that the Germans' extensive use of means of psychological influence in respect of the $128^{\text {th }}$ Rifle Division between May and July 1944 suggests that the Germans were undertaking a full-scale psychological operation in the area. In that period, the Germans employed a whole range of propaganda methods and tools from leaflets and audio broadcasting to collaborationist units of the Russian Liberation Army on the front line. Neither before nor after that period had the $128^{\text {th }}$ Division been subjected to a psychological impact that extensive.

Keywords: World War II, Eastern Front, propaganda, Vlasovtsy, leaflets, audio broadcasting, $128^{\text {th }}$ Rifle Division, Wehrmacht.

\section{Introduction}

The arsenal of psychological tools and methods employed during World War II by the Wehrmacht has been discussed quite extensively in the literature. Worthy of particular mention in this respect are the memoirs of former specialists in the area of propaganda, like those of W.K. Strik-Strikfeldt (Shtrik-Shtrikfel'dt, 1993) and S.B. Fröhlich (Frelikh, 1990), as well as certain works on the history of psychological operations (e.g., Krys'ko, 1999). The author of the present work employed a different approach - study a set of daily operational and intelligence reports from the headquarters of the $128^{\text {th }}$ Rifle Division, extract from them everything related to psychological operations, and systematize those materials.

\section{Materials and methods}

The author drew upon a large array of materials from the Central Archive of the Ministry of Defense (Podolsk, Russian Federation). Use was made not only of operational and intelligence reports from the headquarters of the $128^{\text {th }}$ Rifle Division but intelligence from the fire support team, as well as the operations record books of the regiments and divisions involved. 
Methodologically, in reliance on the principles of objectivity and historicism, the author sifted through every archive material on the subject available. Importantly, use was also made of a systems approach, with all the relevant propaganda influence facts being arranged and systematized based on the chronological principle.

\section{Discussion}

The subject of psychological operations on the Eastern Front during World War II has been discussed in the literature quite extensively. This body of research may be divided into the following two major categories: 1) literature on general issues of psychological warfare; 2) literature on the history of specific psychological operations.

In terms of the first category, worthy of particular mention are V.G. Krys'ko's 'Secrets of Psychological Warfare' (Krys'ko, 1999) and A.V. Okorokov's 'The Special Front: German Propaganda on the Eastern Front during the Second World War' (Okorokov, 2007). Another work that merits serious consideration is M.I. Semiryaga's 'Collaboration: Its Nature, Typology, and Manifestations during the Second World War', which is dedicated to the history of Soviet collaborationism (Semiryaga, 2000). In addition, F.M. Sergeev provides a glimpse into the secret operations of German intelligence (Sergeev, 1991), while A.M. Mamadaliev offers an insight into propaganda on the Eastern Front in the early period of World War II (Mamadaliev, 2015).

In terms of the second category, worthy of special mention is research by the following scholars: V.A. Nesterenko, with his insight into the Eastern Scorpion operation (Nesterenko, 2015), D.A. Zhukov and I.I. Kovtun, with their glimpse into the Gray Head operation (Zhukov, Kovtun, 2015), and E.F. Krinko, with his account of German propaganda in the North Caucasus (Krinko, 2014). The subject of Ukrainian nationalism during World War II is discussed in a study by A.A. Cherkasov, E.F. Krinko, and M. Shmigel' (Cherkasov et al., 2015). S.I. Degtyarev views the Russian Liberation Army as a propaganda project of the Third Reich (Degtyarev, 2015). The collaborationist periodical press in Kursk Oblast is discussed in a work by S.V. Bogdanov and V.G. Ostapuk (Bogdanov, Ostapuk, 2016). A.A. Kokhan supplies an insight into the activity of the collaborationist newspaper Golos Kryma [The Voice of Crimea] (Kokhan, 2016).

\section{Results}

As already mentioned earlier in this paper, its primary purpose was to examine the arsenal of psychological tools and methods employed by the Wehrmacht in respect of the units of the Red Army's $128^{\text {th }}$ Rifle Division. In late March 1944, the division moved to its new defensive area around the city of Pskov (Pskov was being held by the Wehrmacht at the time) (TsAMO. F. 7178. Op. 69301. D. 1. L. 21), and over the course of several months, up until July 22, the opposing sides would largely engage in positional warfare. During the German occupation of Pskov, the city became a major center for the formation of the Russian Liberation Army (RLA), with the RLA having its own units, its own newspaper (Za Rodinu), and even its own song and dance band based there.

The personnel of the $128^{\text {th }}$ Rifle Division first experienced the impact of the Germans' psychological warfare about two weeks after taking up a defensive line at Pskov. This took place on April 15, 1944. At 9:30 pm, an enemy plane dropped leaflets in Russian in the vicinity of the village of Ogurtsovo (TsAMO. F. 1345. Op. 1. D. 45. L. 31-31ob.). It is to be noted that the division had witnessed more than once the enemy distributing leaflets by dropping them from an airplane in the period 1941-1943 as well, so that was not something new.

However, starting in May, the enemy employed the entire spectrum of its psychological weapons - and that was done quite frequently, as often as several times a week.

On May 1, at 11:40 pm the enemy began to conduct agitation over the radio (TsAMO. F. 1345. Op. 1. D. 44. L. 2) using short-range audio broadcasting stations.

The following day, on May 2, the enemy conducted radio agitation between 3 am and 4:30 am (TsAMO. F. 843. Op. 1. D. 86. L. 19). The rationale behind the use of audio broadcasting stations in the nighttime was that in a climate of nighttime silence a much greater sound transmission range could be achieved. In addition, as per specialists in psychological warfare, propaganda tends to have a better effect on the enemy in the nighttime, as there is a possibility of security sentries taking their time to think about the source of an agitation effort and the messages communicated by it. Another factor was that in the daytime it was easier to spot an audio broadcasting station and then attack it with mortar and artillery fire. 
Preses cicoompliti

\begin{tabular}{|c|c|c|}
\hline Ne 73 & Четеерг, 3 дека6ра 1942 года & Немa 50 mon. \\
\hline & & \\
\hline
\end{tabular}

чИтАЙTECETO DH Я:

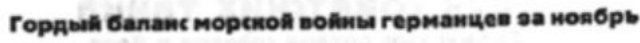

Cтапим эa 10 дмей noтерan 1024 танка

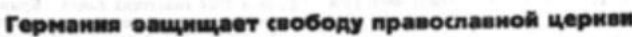

\section{Снова гордое сообщение об успехах германского орухсия

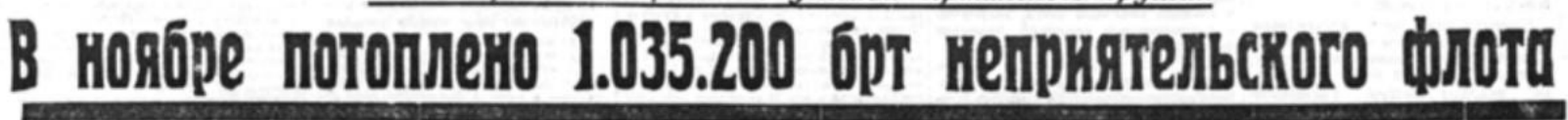

Развал семьи B CCCP

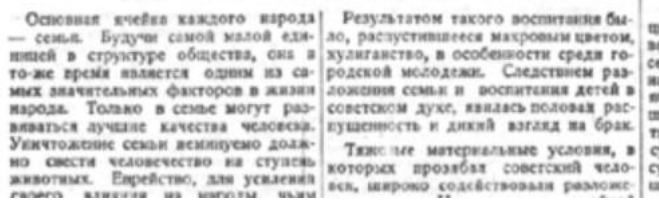
Врагу манесен самый тяжелый удар с пачапа войны. -
Германские подводные лодки в ноябре потопипи почти 1 мпк. 6рт судов противника

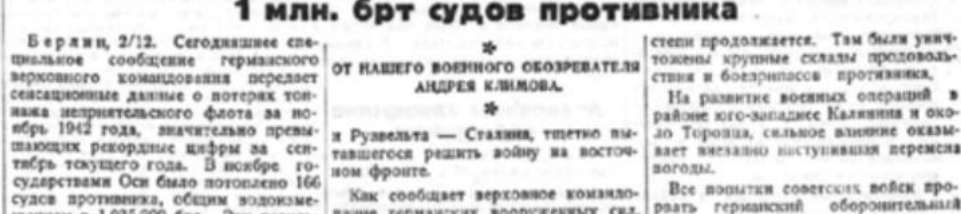

Fig. 1. Leading article in the December 31942 issue of the Za Rodinu

[For the Motherland] newspaper

In the meantime, on May 6 whole new events began to take place in the area of operation of the $128^{\text {th }}$ Rifle Division, something the division had not experienced since the beginning of the war - the use of collaborationist units on the front line against the Red Army. May 6 is actually when the first "acquaintance" took place. On the eve of that day, the division's recon team seized from the Wehrmacht outpost an area code named 'Forester's Cabin'. In an attempt to regain their positions, the Germans launched a counter-offensive. More specifically, at 11:50 am five enemy soldiers appeared from the forest outside the front of the $4^{\text {th }}$ Rifle Company of the $374^{\text {th }}$ Rifle Regiment of the $128^{\text {th }}$ Division, gesturing in the direction of the regiment's lines and shouting 'hurrah', subsequent to which a group of another 15 men ran out of the forest shouting the same word. All infantry resources of the $4^{\text {th }}$ Rifle Company were employed to open concentrated fire on the men, which resulted in three of them being killed and two wounded, with the rest fleeing back into the forest (TsAMO. F. 843. Op. 1. D. 86. L. 28). Despite the failure, the RLA moved up artillery and mortar guns and relaunched the offensive on May 9. This is indicated by a report of the headquarters of the $128^{\text {th }}$ Rifle Division. According to the report, on May 9 at $10 \mathrm{pm}$, subsequent to a 20-minute-long artillery strike, the enemy, represented by three groups with a combined membership the size of a company, proceeded along the left bank of the River Pskova and with shouts of 'hurrah' and 'surrender, Rus' attacked the $6^{\text {th }}$ Rifle Company of the $741^{\text {st }}$ Regiment. Superior numerically and with covered routes of approach to the regiment's main line, the enemy concentrated dense artillery fire on the company's lines. At the expense of heavy losses, the enemy drove back the $2^{\text {nd }}$ Platoon of the $6^{\text {th }}$ Company and tried to cut off and trap the $1^{\text {st }}$ Platoon. The enemy managed to capture 40 meters of the enemy's trenches. Following a two-hour hand-to-hand battle, the enemy was forced to retreat to its initial positions, after sustaining heavy losses from infantry and artillery fire. From grenades, infantry fire, and artillery fire the Germans sustained about 45 casualties. The following spoils were captured: two light machine guns, two rifles, and several ammunition belts. The $741^{\text {st }}$ Rifle Regiment sustained four dead and three wounded (TsAMO. F. 1345. Op. 1. D. 44. L. 24-24ob.). The participation of former Soviet citizens in battle against the Soviet army had a powerful psychological effect, as it violated the doctrine about the unity of the Soviet people in the fight against the aggressor. The antagonism between the Vlasovtsy and the Soviet servicepersons was so pronounced that both sides would normally take no prisoners.

On May 16, the enemy employed audio broadcasting again. The division's headquarters reported that the enemy conducted radio agitation at 2:30 am and at 4:30 am (TsAMO. F. 1345 . Op. 1. D. 44. L. 43). 
Two days later, on May 18, watching the enemy helped establish that at $7 \mathrm{pm}$ the enemy released from the vicinity of Pskov eight balloons with leaflets (TsAMO. F. 1345. Op. 1. D. 44. L. 52). Balloons of this kind had been developed back during World War I, with both Germany and the Entente employing them actively at the time.

On May 21, there took place as many as four events of a psychological nature. Specifically, the enemy conducted radio agitation in Russian outside of the front of the $374^{\text {th }}$ Regiment at 12 am and at 12:30 am. To this the Russians responded with mortar fire. Between $2 \mathrm{pm}$ and 2:30 pm, an enemy plane dropped six balloons with leaflets, with one of them landing in the village of Yazykovo and the rest being carried away eastwards (TsAMO. F. 1345. Op. 1. D. 44. L. 59). It was the first time that the division's headquarters had witnessed leaflet-carrying balloons being dropped from an airplane by the enemy in that period.

On May 24, the enemy's audio broadcasting station resumed work. Specifically, an agitation transmitter was used from 12 am to 1 am (TsAMO. F. 843. Op. 1. D. 86. L. 66). The report from the division's headquarters does not record an effort to counteract the activity.

Another six days later, on May 30, the enemy conducted broadcasting toward the $128^{\text {th }}$ Rifle Division again. According to the report from the division's headquarters, the enemy conducted agitation in Russian at 2:15 am (TsAMO. F. 1345. Op. 1. D. 44. L. 95).

Thus, in May, the enemy conducted broadcasting six and dropped leaflets two times, while the Vlasovtsy confronted the Red Army on the battlefield twice, too.

On June 12, men could be heard conversing in Russian in the trenches of the enemy's main line south of the village of Klishevo (TsAMO. F. 843. Op. 1. D. 86. L. 106). This provided indirect confirmation that there were RLA units present in this part of the front line.

The following day, the enemy resumed radio broadcasting. Specifically, on June 13 at 1 am the enemy conducted radio broadcasting in broken Russian from the vicinity of the village of Luni. The following was overheard in the broadcast: "Come over to our side. The Allies are having unsuccessful operations on the northwestern coast of France. We are constantly destroying the Allies' troops disembarking there". In addition, at 1:45 am men were heard working with axes and conversing in Russian in the enemy's zone (TsAMO. F. 1345. Op. 1. D. 44. L. 145).

On June 14, the enemy used an audio broadcasting station to conduct agitation again. Specifically, the operational report from the division's headquarters stated the following: "At 1:30 am the enemy conducted radio broadcasting in broken Russian from the vicinity of the Luni sovkhoz. Due to poor audibility, it was not possible to establish the contents of the broadcast" (TsAMO. F. 843. Op. 1. D. 86. L. 109). The fact about the broadcasting being in broken Russian is quite an interesting one, given that German propagandists were insisting on using either deserters who used to serve with the same unit toward which broadcasting was going to be conducted or girls from the local population. Considering that the Germans should have had no problem finding the right girls in Pskov, where there was in operation at the time a facility for training nurses for the RLA, it is somewhat strange that they broadcasted in broken Russian.

In the daytime of June 18, the enemy resumed its psychological warfare. Specifically, at 11:45 am the Germans released three agitation balloons with leaflets (TsAMO. F. 1345. Op. 1. D. 44. L. 163).

As early as June 20, the Germans' audio broadcasting station resumed broadcasting. The report states the following to that effect: "At 12:40 am the enemy used a radio transmitter to broadcast in Russian into the zone of the $741^{\text {st }}$ Rifle Regiment” (TsAMO. F. 1345. Op. 1. D. 44. L. 169).

The division's observers and listeners-in (persons concerned with listening in to enemy communications in the nighttime) were watching the enemy closely, and on June 26 at 12:45 am they detected in the enemy's main line shouts and laughter that came from people who spoke Russian (TsAMO. F. 1345. Op. 1. D. 44. L. 186).

Thus, in June there was a decline in the number of acts of psychological influence by the Germans in the area - just three audio broadcasting sessions, two instances of collaborationist units being used in the enemy's main line, and one instance of leaflets being distributed.

July witnessed a few cases of this kind as well. Specifically, the enemy launched a radio broadcast at 12 am on July 5 (TsAMO. F. 1345. Op. 1. D. 44. L. 216).

Two days later, on July 7 , the enemy resumed broadcasting. The report from the division's headquarters states that at 1:30 am the enemy conducted agitation over the radio (TsAMO. F. 1345. Op. 1. D. 44. L. 220). 
On July 9, it was established through the division's observers and listeners-in that the enemy was conducting some engineering work, with axes and saws being used. Russian women were heard laughing. The nature of the activity was not established (TsAMO. F. 1345. Op. 1. D. 44. L. 224). This was the last recorded case of psychological influence in the area.

The first decade of July witnessed three instances of psychological influence in the area twice via audio broadcasting and once via collaborationist units.

It must be taken into consideration that in July the Germans were preparing Pskov for evacuation, with many RLA organizations based in the city being moved to the rear in the final days prior to the Soviet advance, and as early as July 22, 1944, the $128^{\text {th }}$ Rifle Division launched an offensive with the aim of seizing the city of Pskov, which would result in it coming to be called '128 ${ }^{\text {th }}$ Pskov Rifle Division' (TsAMO. F. 7178. Op. 69301. D. 1. L. 22).

Overall, between May and July 1944 the $128^{\text {th }}$ Rifle Division was subjected to a broad spectrum of psychological influence. There were nearly 20 recorded cases alone, with 11 of those being a case of psychological influence by way of audio broadcasting, five being a case of influence by way of being pitted against compatriots on the front line (twice in combat), and three being a case of influence by way of leaflet distribution. The operational reports from the headquarters of the $128^{\text {th }}$ Rifle Division did not say anything about the actual effect of these psychological operations.

\section{Conclusion}

The Germans' extensive use of means of psychological influence in respect of the $128^{\text {th }}$ Rifle Division between May and July 1944 suggests that the Germans were undertaking a full-scale psychological operation in the area. In that period, the Germans employed a whole range of propaganda methods and tools from leaflets and audio broadcasting to collaborationist units of the Russian Liberation Army on the front line. Neither before nor after that period had the $128^{\text {th }}$ Division been subjected to a psychological impact that extensive.

\section{References}

Bogdanov, Ostapuk, 2016 - Bogdanov, S., Ostapuk, V. (2016). Mass Collaborationist Print Media in the Kursk region during the German Occupation. Propaganda in the World and Local Conflicts. 6(2): 68-77.

Cherkasov et al., 2015 - Cherkasov, A.A., Krinko, E.F., Shmigel', M. (2015). Ukrainskii natsionalizm $\mathrm{v}$ gody Vtoroi mirovoi voiny: priroda i proyavleniya [The ukrainian nationalism during the Second World war: nature and manifestations]. Rusin. 2(40): 98-117. [in Russian]

Degtyarev, 2015 - Degtyarev, S.I. (2015). Russian Liberation People's Army as a Propaganda Project of the Third Reich. Propaganda in the World and Local Conflicts. Vol. (3). Is. 1: 26-31.

Frelikh, 1990 - Frelikh, S.B. (1990). General Vlasov. Russkie i nemtsy mezhdu Gitlerom i Stalinym [Russians and Germans between Hitler and Stalin]. Kel'n. [in Russian]

Kokhan, 2016 - Kokhan, A.A. (2016). «Moya ideologiya byla chuzhda ideologii sovetskogo cheloveka»: k voprosu o sostave i deyatel'nosti redaktsionnoi kollegii gazety «Golos Kryma» v 19411944 gg. ["My ideology was alien to the ideology of the Soviet man": on the question of the composition and activities of the editorial board of the newspaper "Voice of Crimea" in 1941-1944.]. Vestnik RGGU: Istoriya, Filologiya, Kul'turologiya, Vostokovedenie. 10(19): 154-164. [in Russian]

Krinko, 2014 - Krinko, E.F. (2014). The Nazi Propaganda in the North Caucasus: the Forms and Methods. Propaganda in the World and Local Conflicts. 2(2): 94-108.

Krys'ko, 1999 - Krys'ko, V.G. (1999). Sekrety psikhologicheskoi voiny [The secrets of psychological war]. Pod obshch. red. A.E. Tarasa. Minsk. [in Russian]

Mamadaliev, 2015 - Mamadaliev, A.M. (2015). Fighting and Propaganda Activities on the Eastern Front in 1941-1942. Propaganda in the World and Local Conflicts. 4(2): 56-64.

Nesterenko, 2015 - Nesterenko, V.A. (2015). A Few Words about the Third Reich Propaganda Operations in 1944. Propaganda in the World and Local Conflicts. 4(2): 117-119.

Okorokov, 2007 - Okorokov, A.V. (2007). Osobyi front: Nemetskaya propaganda na Vostochnom fronte $\mathrm{v}$ gody Vtoroi mirovoi voiny [The special front: german propaganda on the Eastern front during the Second world war]. Moscow. 288 p. [in Russian]

Semiryaga, 2000 - Semiryaga, M.I. (2000). Kollaboratsionizm. Priroda, tipologiya i proyavleniya $\mathrm{v}$ gody Vtoroi mirovoi voiny [Collaboration. Nature, typology and manifestations during the Second World War]. M. [in Russian] 
Sergeev, 1991 - Sergeev, F. (1991). Tainye operatsii natsistskoi razvedki, 1933-1945 gg. [Covert operations of Nazi intelligence]. Moscow. [in Russian]

Shtrik-Shtrikfel'dt, 1993 - Shtrik-Shtrikfel'dt, V.K. (1993). Protiv Stalina i Gitlera [Against Stalin and Hitler]. Moskva. [in Russian]

TsAMO - Tsentral'nyi arkhiv ministerstva oborony Rossiiskoi Federatsii [The Central Archives of the Ministry of Defence of the Russian Federation].

Zhukov, Kovtun, 2015 - Zhukov, D., Kovtun, I. (2015). Operatsiya «Sedaya golova» [The operation "Gray head”]. Sovershenno sekretno. 14 maya. [in Russian] 